\title{
The unique fossil assemblage from the Lode Quarry (Upper Devonian, Latvia)
}

\author{
Ieva Upeniece ${ }^{1}$
}

With 2 figures, 4 colour-plates, and 2 tables

\begin{abstract}
The unique fossil fauna from the Lode clay quarry, lower Frasnian, Latvia, includes a diverse ichthyofauna of at least 15 taxa of agnathans and gnathostomes, representing most of the major taxa of Devonian vertebrates. Six new fish taxa (five species and one genus) were discovered during the last ten years. Exceptionally well-preserved juvenile fishes (Asterolepis ornata. Lodeacanthus gaujicus) provide unique data on ontogenetic change. Diverse arthropods are recorded. Parasitic platyhelminth remains in juvenile fish bodies is their first discovery in the fossil record, and represents the oldest parasitic association ever found. A complete faunal and floral list for the Lode quarry is presented, with a detailed biostratigraphic scction. Comparison of vertebrata taxa from the Gauja Regional Stage with similar of the Main Devonian Field, Scotland, Timan, Canada, and Germany is reviewed.
\end{abstract}

Key words: Lode fossil assemblage, juvenile fishes, parasitic platyhelminths, Lode quarry, lower Frasnian, Upper Devonian, Latvia, Main Devonian Field.

\section{Zusammenfassung}

Die einzigartige Lebensgemeinschaft von Lode repräsentiert eine diverse Fischfauna nahezu aller Hauptwirbeltiertaxa. die im Devon lebten. Sechs neue Fischtaxa (5 Arten und 1 Gattung) wurden in den letzten zehn Jahren in den Unter-FrasniumSchichten der Ziegeleigrube von Lode in Lettland entdeckt. Insgesamt sind 15 identifizierte und unbestimmte Fisch- und Agnathen-Arten von dort bekannt. - Besondere Beachtung wurde den außergewöhnlich gut erhaltenen Jugendformen von Asterolepis ornata und Lodeacanthus gaujicus und verschiedenen Invertebraten (Crustacea, Merostomata) gespendet. dic in einer einzigen Linse fein verteilten Tones gefunden wurden. Reste parasitischer Platyhelminthen, die in Jungfischen auftreten. wurden hier zum ersten Mal als Fossilien entdeckt; sie repräsentieren die älteste bisher gefundene parasitische Gemeinschaft. Eine Liste der organischen Reste aus den Schichten der Ziegeleigrube Lode wird präsentiert. Ein detailliertes biostratigraphisches Profil wird beschrieben. Die Fischfaunen aus der Gauja Regional-Stufe werden mit denen vom Hauptdevonfeld Russlands, von Schottland, dem Timan, Kanadas und Deutschlands verglichen.

Schlüsselworte: Lebensgemeinschaft von Lode, Jungfische, parasitische Platyhelminthen, Ziegeleigrube Lode, unteres Frasnium, Oberdevon, Lettland, Hauptdevonfeld.

\section{Introduction}

The Lode clay quarry (lower Frasnian, Upper Devonian, Latvia) is famous for the abundance and variety of exceptionally well-preserved Devonian vertebrate and invertebrate fossils, and aquatic and terrestrial plant remains (Kuršs et al. 1999, Upeniece 2000). It has been assessed as one of the most representative fossiliferous sites of the Devonian (Cloutier \& Lelièvre 1998). Lode fossil assemblage (Table 1) stands out from all the other Devonian sites in terms of faunal, environmental and paleobiological representa- tiveness, biodiversity and excellent preservation. The aim of the paper is to present the unique fossils of abundant juvenile fish, their parasitic helminths, diverse crustaceans and plant fossils, collected in a separate "juvenile fish" lens of fine-dispersed clays during the yearly excavations between $1988-1998$ by the author.

Located in the north-eastern part of Latvia (Fig. 1), the Lode clay quarry became widely known after exceptionally preserved fossil fishes were discovered by V. Kuršs in 1970. Several hundred complete articulated individuals of three fish species were reported by Lyarskaya \&

\footnotetext{
1 Institute of Geology, University of Latvia, Rainis Blvd. 19, Rīga LV 1586, Latvia. e-mail: upeniece@lanet.lv

Received May 2001, accepted July 2001
} 

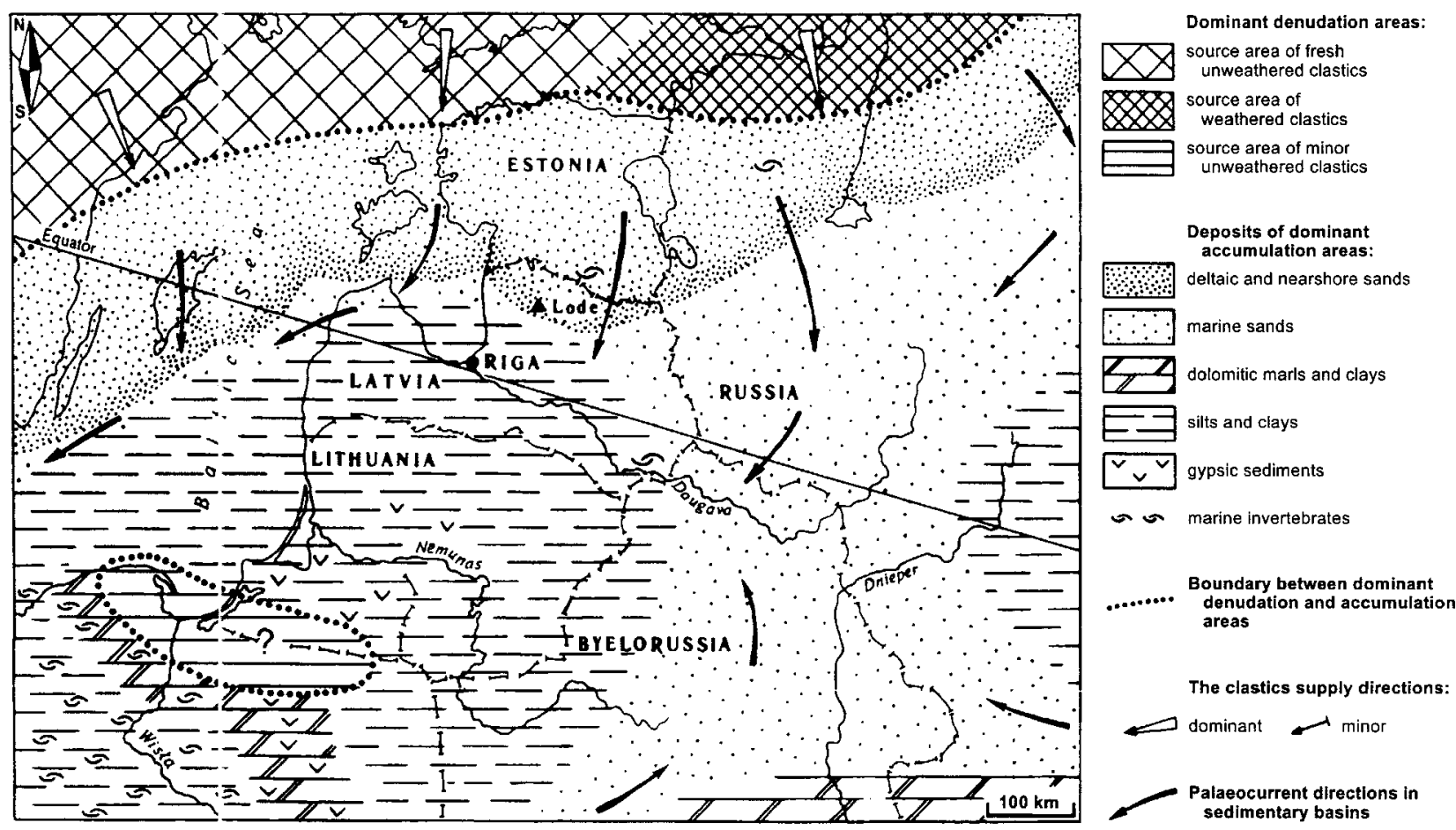

Fig. 1. Palaeogeog aphical map of the Devonian terrigenous sedimentation in the late Givetian (Burtnieki Regional Stage) and carly Frasniar (Gauja Regional Stage) in the East Baltic (after V. Kuršs 1992a, fig. 37c). The Lode Formation stretches along the paleoslope for a distance between towns of Césis and of Pechori.

Mark-Kurik ( 972): the placoderm Asterolepis ornata Eichwald sensu Agassiz, 1840, and the sarcopterygian; Laccognathus panderi Gross, 1941 and Penderichthys rhombolepis (Gross 1941). In addi ion, isolated plates of Psammolepis paradoxa Agassiz, 1844 were recognized in the red siltstones.

Fossil fish material was collected in the 1971-72 and :976 field seasons. Numerous publications on the morphology of adult Asterolepis ornata and Panderichthys rhombolepis followed: Lyarskaya \& Mark-Kurik (1972), Lyarskaya (1972, 1977, 1981), Worobjewa (1973, 1975), Vorobjeva (1980, 1989, 1995), Vorobjeva \& Schultze (1991), Ivanov et al. (1996), Ahlberg et al. (1996). Sedimentological and taphonomical aspects of the Lode quarry have been studied by Kuršs (1975, 1986, 1992a, 1992b). Kuršs \& Lyarskaya (1973), Kuršs et al. (1998, 1999), and Upeniece $(1991,1599 \mathrm{a})$.

The sediments of the Gauja Regional Stage with its Asterc lepis ornata assemblage in Latvia is assumed to represent terrigenous sedimentation of the earliest Frasnian. The precise correlation with miospore or conodont standard zonations remains 'nclear regarding the stratigraphic position of the Givetian/Frasnian boundary within the Gauja Regional Stage (Mark-Kurik 1999. Blieck et al. 2(00, Esin et al. 2000). After Meyen (1987: 312), the Archaeopteris zone in associa- tion with Platyphyllum characterises the Frasnian-lower Fammenian. Both plant remains are common fossils in the Lode quarry.

Specimens prefixed with LDM (Latvijas Dabas muzejs) are housed in the Latvian Museum of Natural History, Rīga; prefixed $\mathrm{MB}$ in the Museum of Naturkunde, Berlin; prefixed with UP - are in a private collection of Mr. Jānis Upenieks. Rigga (Arthropoda and problematic remains). After the taxonomic description the latter specimens will be housed in LDM.

\section{Geologic setting}

The Lode Formation occurs within a $200 \mathrm{~m}$ thick succession of sandstones, siltstones and clays of Middle-Upper Devonian clastics on the Main Devonian Field, and corresponds to the upper part of the Gauja Regional Stage. Kuršs (1975, 1992a) studied its distinct sedimentological features and lithological composition, unusual for the Old Red facies. The sediments of the Lode Formation are preserved for a distance of 160 $\mathrm{km}$ along the palaeoslope, extending from the $\mathrm{N}$ E part of Latvia (Cēsis town) to the S-E part of Estonia, and disappear to the $\mathrm{E}$ of the Pechori in the Pskov District of NW-Russia (Fig. 1). The Lode Formation forms large lenses of finely dispersed clays and siltstones within the marine-del- 
taic sandstones of the Sietini Formation (lower part of the Gauja Regional Stage). Clayey mud has accumulated in the slump and local bottom depressions on the submarine delta slopes, with brecciated material in the base of depressions. The slope reaches $30-70^{\circ}$. The meridionally arranged depressions are from several tens to 200-300 metres long.

Lode quarry is the type locality of the Lode Formation, and exposes a structurally complex sequence, with specific slump and dislocation structures. Units can be correlated for several tens to hundreds of metres. The average thickness of the formation comprises $30 \mathrm{~m}$, the maximum of $104 \mathrm{~m}$ was recorded in a borehole (Kuršs 1975). Phosphorite nodules with fragments of fish bones and conchostracans, as well as sulphite and ferruginous-phosphatic nodules, occur in sandstones alongside the depression slopes. Black sooty uranium-molybdenium accumulations occur in sandy interlayers within the clayey beds (Kuršs 1992a).

Sedimentation rates were high in this area, up to several metres (?) per year (Kuršs 1992b). Rapid entombment in the fine mud protected the delicate organisms from decay and disintegration, and in turn, the finely grained sediments resulted to a high-extent of fossilisation. Stagnant bottom waters developed a toxicity that rendered them uninhabitable by benthic animals, prevented rapid bacterial decay and permitted the accumulation of soft organic matter. Rapid burial could have been influenced by the abnormal silting from land in periods of heavy rains as it is known in modern environments (Gunter 1947).
The completeness of preservation and minimal distortion of both juvenile and adult fish fossils indicate negligible post-mortem transport. Intact remains of fishes usually occur in fine-dispersed clay lenses of various width; disarticulated ones - in fish-bone bearing siltstone layers of secondary concentration.

To the west of Cēsis the Gauja Regional Stage is represented only by the undivided Gauja Formation, comprising sandstones and overlying siltstones with the equal taxa of the Sietini Formation.

The Devonian seas of the Baltic region were located on the continental shelf, thus being epicontinental, comparatively shallow, and supporting a rich fauna and flora. The dense fish populations in deltaic regions were determined by the abundance of their presumed food resources small invertebrates and plant detritus.

\section{Faunal and floral characteristics of the Lode Quarry}

Subsequent excavations in the Lode clay quarry added much to the first reported four vertebrata taxa (Kuršs \& Lyarskaya 1973). The faunal list now includes almost all major taxa of vertebrates living during the Devonian: agnathans, placoderms, acanthodians, actinopterygians and sarcopterygians, with at least 15 species and 13 genera (Table 1). In addition there are at least five major invertebrate groups, and eight taxa of plant macro- and microremains. Coprolites and problematic soft-body organism remains are also common.

Table 1

List of fauna and flora recovered from the Lode Quarry (Lode Formation).

\begin{tabular}{|c|c|c|}
\hline Vertebrata & Invertebrata & Flora \\
\hline $\begin{array}{l}\text { Psammolepis alata Mark-Kurik, } 1965 \\
\text { Psammolepis paradoxa Agassiz, } 1844 \\
\text { Asterolepis ornata Eichwald sensu Agassiz, } 1840 \\
\text { Lodeacanthus gaujicus Upeniece, } 1996 \\
\text { Cheirolepis sp. } \\
\text { Dipteridae gen. et. sp. indet. } \\
\text { Miguashaia grossi Forey, Ahlberg, Lukševičs } \\
\text { and Zupinsš, } 2000 \\
\text { Coelacanthidae gen. et sp. indet. } \\
\text { Strunius n. sp. } \\
\text { Glyptolepis baltica Gross, } 1930 \\
\text { Laccognathus panderi Gross, } 1941 \\
\text { Latvius n. sp. } \\
\text { Osteolepididae gen. et sp. indet. } \\
\text { Eusthenopteron n. sp. } \\
\text { Panderichthys rhombolepis (Gross, 1941) }\end{array}$ & $\begin{array}{l}\text { Platyhelminthes } \\
\text { Eurypterida } \\
\text { Conchostraca: } \\
\text { Pseudestheria sp. } \\
\text { Mysidaceae } \\
\text { (ichnofossils, problematic remains) }\end{array}$ & $\begin{array}{l}\text { Nematophyton } \mathrm{sp} . \\
\text { Platyphyllum } \mathrm{sp} . \\
\text { Charales (?) } \\
\text { Trochilliscus } \mathrm{sp} . \\
\text { Svalbardia polymorpha Høeg, } 1942 \\
\text { Archaeopteris fissilis Schmalhausen, } 1894 \\
\text { Archaeopteris sp. } \\
\text { Rhacophyton sp }\end{array}$ \\
\hline
\end{tabular}



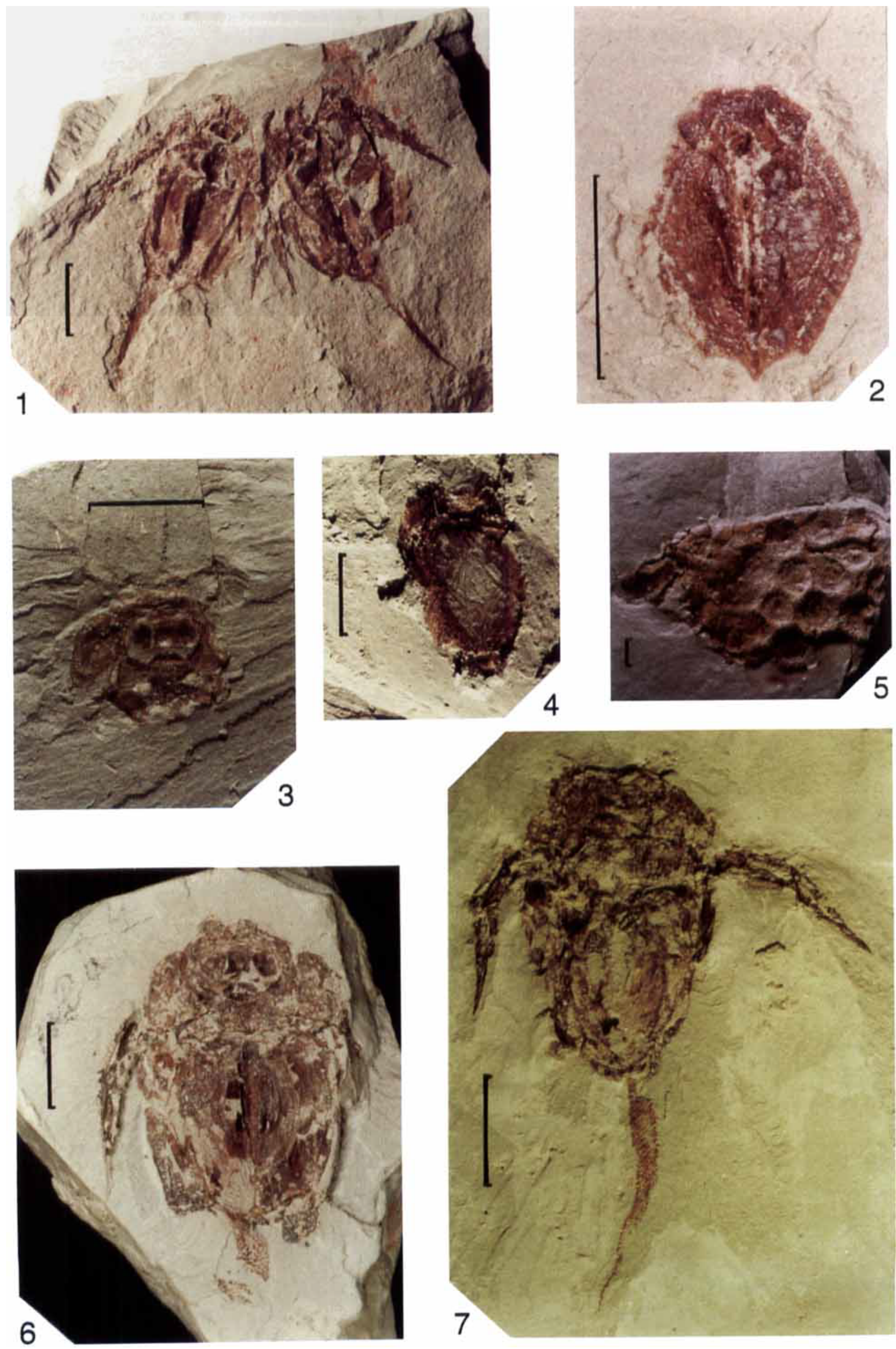
Five new species and one new genus have been discovered during the last ten years. The acanthodian Lodeacanthus gaujicus Upeniece, 1996 is represented by juveniles and adults. New species of the sarcopterygians Strunius n. sp. and Latvius n. sp. are recorded (Upeniece 1995, 1996). The first coelacanth from the Baltic Devonian (Miguashaia grossi) has been described by Forey et al. (2000), and Zupiņš (2000, 2001) reports on a complete articulated specimen of Eusthenopteron n. sp., as well as on important new material of Glyptolepis baltica Gross, 1930.

The placoderm Asterolepis ornata is the most abundant component of vertebrate fauna, with both adult and juvenile individuals (Col.-Pl. 1: 1-4, 6-7). An extensive collection of juveniles of the antiarch Asterolepis ornata from Lode was partly described and figured by Upeniece \& Upenieks (1992). Some 35 adult Asterolepis ornata bodies, disintegrated to different degrees, were exposed in 1988, allowing study of the disarticulation process (Upeniece 1999a). This taphocoenosis contains both articulated - possibly unfloated skeletons (that did not undergo postmortem flotation) with removed anterior median dorsal plates (AMD) due to the internal pressure of decomposition gases, incomplete, previously as well as floated ones. Actuopaleontological investigations show that in cold waters below $16^{\circ} \mathrm{C}$, most carcasses do not float but remain on the bottom until buried (Elder \& Smith 1988). Obviously these fishes were not killed by one event. Fish were accumulated in a local depression (Kuršs 1992a: fig. 34) with some influence of weak submeridional currents (Upeniece 1999a, figure) and covered by $15-25 \mathrm{~cm}$ thick laminae of finely-dispersed and silty clays. A small clay layer with abundant vertical ichnofossils (Col.-Pl. 2: 11) occurs immediately below this fish-bearing clay layer. Ichnofossils only very rarely occur in the Lode quarry. The basal part of the rhythmic sequence consists of a $0.3 \mathrm{~cm}$ thick sandstone layer. Several skeletons of $\mathrm{Lac}$ cognathus panderi, as well as some plates of Psammolepis alata Mark-Kurik, 1965 were also exposed in this lens.
The asterolepids of the first excavations in the 70-ies, mentioned in the introduction, were dominated a number of times over the sarcopterygians. The fishes were deposited in a clay lens (thickness $3 \mathrm{~m}$ ) in three fish-bearing layers of area $5 \times 20 \mathrm{~m}$ (Lyarskaya \& Mark-Kurik 1972). Fifty-eight individuals of adult Asterolepis ornata, four of Laccognathus panderi, and one of Panderichthys rhombolepis were found in the lower and richest fish-bearing layer of the lens. In the second layer the asterolepids comprise only $25 \%$; in the third - domination of asterolepids again (exact number is not stated for these two layers), and sarcopterygians occur only as incomplete specimens. The skeletons of asterolepids are slightly deformed and often found in a position with their dorsal sides upward, clinging close to each other. The sarcopterygians are considerably flattened. The orientation of the specimens is various, for the asterolepids it tend to be the submeridional, for the lobe-finned fishes sublatitudinal (Lyarskaya 1981: 39, fig. 11). It seems that such orientation must have been determined by the different size and heaviness of the body in these distinct groups: weak bottom currents rather easily transported the cadavers of asterolepids in contradistinction to the big and heavy sarcopterygians, which possibly were trundled over the bottom of the basin until burried and resulted in a sublatitude orientation. In the early Frasnian the clastic supply directions in the East Baltic were submeridional (Fig. 1).

The earlier hypothesis, that the Lode taphocoenosis was formed as result of a catastrophic mass mortality event of fish, was based on their occurrences in the upper parts of the sedimentation rhythmic sequence - in grey dispersed clay layers (Kuršs \& Lyarskaya 1973, Lyarskaya 1981). It seemed that the mortality was caused by change of the basin regime. Later the cause was re-evaluated and attributed to a dependence on the hydrodynamic conditions of sedimentation: in basin bottom deeps fish cadavers were accumulated as a result of sorting of organic remains by weak currents, towards the borders of these depressions a great number of separate

Colour-Plate 1. Juvenile individuals of Asterolepis ornata Eichwald sensu Agassiz, 1840 (except 5) found in "juvenile fish" lens, Lode clay quarry, Latvia; lower Frasnian. Scale bar $0.5 \mathrm{~cm}$.

1. Whole-bodied juveniles, internal view. On the left - LDM $260 / 223 \mathrm{a}$, total length $2.25 \mathrm{~cm}$, on the right $260 / 224 \mathrm{a}$, total length $2.61 \mathrm{~cm}$. 2. AMD plate, internal view, LDM 260/248a, length $0.72 \mathrm{~cm}$. 3. Head shield, internal view, LDM 260/266a, length $0.57 \mathrm{~cm}$. 4. Ventral shield with unossified medio-ventral plate, internal view, LDM $260 / 239 \mathrm{a}$, length $0.12 \mathrm{~cm}$. 5. Problematic remains, UP 5/5. 6. Complete specimen of a larger individual, internal view, LDM 260/118a, length $1.8 \mathrm{~cm}$. 7. Whole-bodied juvenile, internal view, LDM $260 / 235 \mathrm{~b}$, length $2.58 \mathrm{~cm}$. 

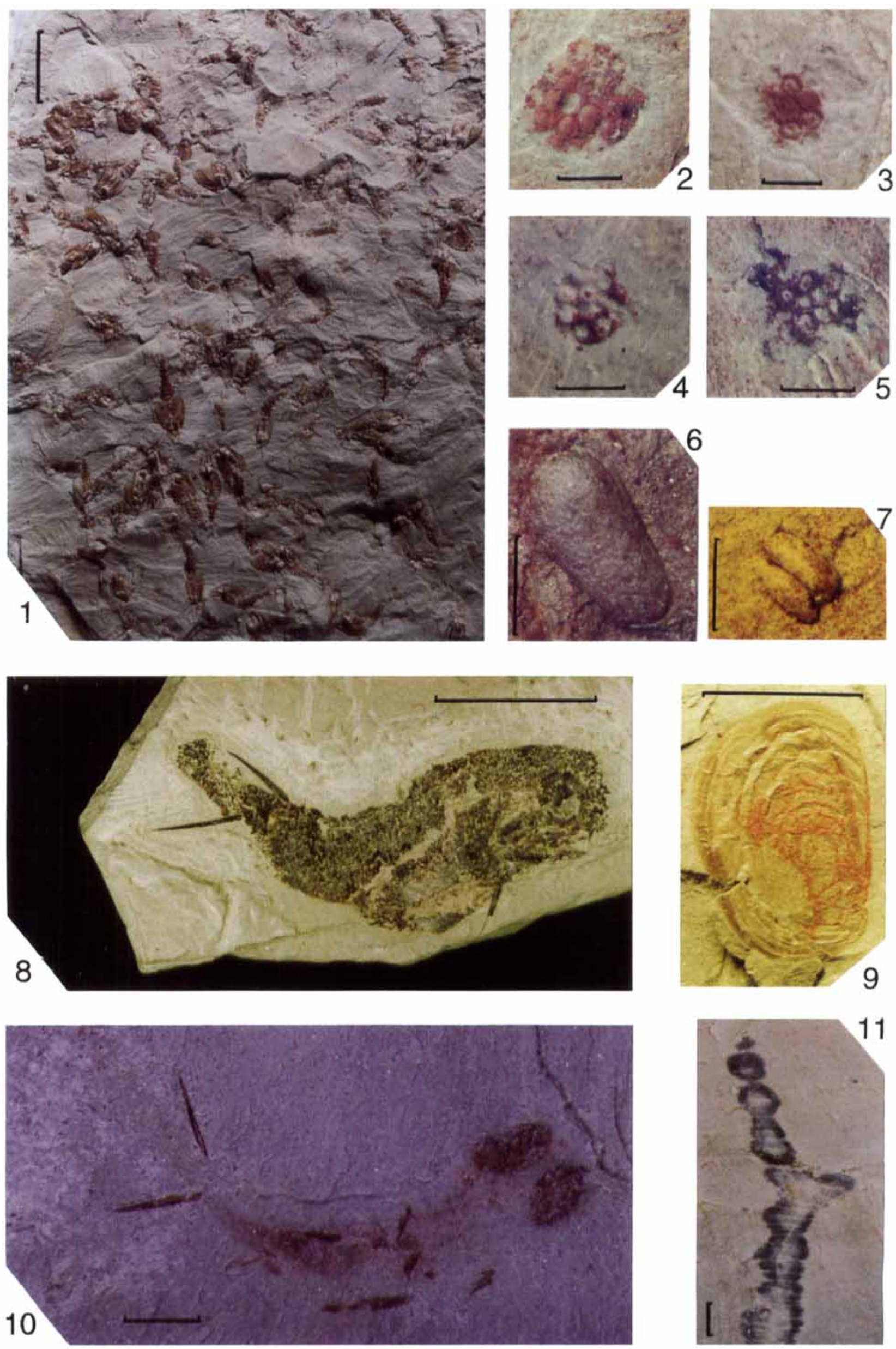
bones accumulated, which quickly decreased along the borders. The colour of clays changed from greenish-grey to variegated and, further, to red (Kuršs 1986, 1992b: text-fig. 3). The same conclusion was attributed after the taphonomical research of juveniles of Asterolepis ornata, found in "juvenile fish" lens (Upeniece \& Upenieks 1992: text-fig. 1), as well as on their adults, studying the sequence of the disintegration stages, mentioned above. These depressions served as local basins for "fish sedimentation".

Well-preserved plant remains of Archaeopteris sp. and Rhacophyton sp. have been found as continuous layer on bedding planes in the basal silty part of the rhythmic deposits during the first excavations (Kuršs 1992b) and identified by A. M. Jurina, Moscow University (Lyarskaya 1981). Fragments of alga Nematophyton sp. are recognized. Other plant remains were found in the "juvenile fish" lens, listed below. Two specimens of ostracods Lepedites sp. were found in the Lode quarry sandstones (Sietingi Formation) by L. Lyarskaya, not mentioned before.

\section{"Juvenile Fish" lens and its fossil assemblage}

The peculiar "juvenile fish" clay lens is a clayfilled slump depression $66 \mathrm{~m}$ wide, which has yielded unique complete fish fry and juvenile fossils, as well as diverse invertebrates, and plants (Upeniece 2000). The juvenile fish-assemblage combines forms from different habitats: including predaceous forms, plankton feeders and benthonic forms, described below. Agnathans are totally absent. The small fish probably were seeking the protection of the shallows and aquatic vegetation characteristic of the littoral environment. The local abundance of mysidaceans and conchostracans makes an ideal link in the food chain between algal phytoplankton and carnivorous fish in the trophic levels of the Lode organism assemblage (Upeniece 2001). Different problematic remains occur (Col.-PI. 1: 5). The almost total absence of a burrowing infauna is characteristic for the lens. All remains of organ- isms of this lens are black or brown in colour. It is contrary to the findings of the whole-bodied adults of asterolepids and sarcopterygians, found in common lenses of yellow-greyish clays in the same quarry: there fish fossils are white or lightcoloured. Part of the fossils are found as fragments because the laminated clays dry out and break.

The lens consists of dense, finely dispersed, organic, dark grey clay laminites (Fig. 2) interbedded within the medium-coarse sandstones. These finely laminated clays are distinctive from the other lenses of the quarry; no significant lithology change indicates a steady environment. The delicate lamination is deformed only by abundant coprolites during their deposition into oozes, as well as by clay "bubbles", the origin of which will be dealt below. The unusual distribution of deep red clay interlayers $(1-3 \mathrm{~cm}$ thick) is characteristic for this lens (Fig. 2, Col.-Pl. 3:1). Random siltstone interlayers and spots of sands appear.

A detailed biostratigraphical section of the "juvenile fish" clay lens (Fig. 2) represents the frequency of fossil distribution: rare (one or very few) and common finds are distinguished. The total thickness of deposits exceeds $12 \mathrm{~m}$, of which $7 \mathrm{~m}$ are rich in fossils. The clay unit had been extended over the top of the outcrop for at least $5 \mathrm{~m}$. Central parts of the lens represent deposition in the deepest water with the majority of articulated fish and dense finds of crustaceans (Upeniece \& Upenieks 1992: text-fig. 1). The thickness of the beds decreases towards the edge of the clay lens; here incomplete fish skeletons and isolated armour plates, as well as rare little slumps (up to $10 \mathrm{~cm}$ ) occur. Siltstone and multicoloured gravelstone-clayey pebbles with clayeysilt cement occur towards the bottom of the clay lens; coarse-grained sediments increase: silty clays, sandstone interlayers, sandy clays and sandstone (Fig. 2). The later represent the Sietingi Formation and the bottom of the slump depression.

The majority of the lens had been already used for brick production before 1984. Actually only a few percent remained due to the yearly

Colour-Plate 2. Invertebrates and acanthodians from "juvenile fish" lens (except 11), Lode clay quarry, Latvia; lower Frasnian. 1. Bedding plane of crustaceans Mysidacea. UP $1 / 1$. Scale bar $1 \mathrm{~cm} . \mathbf{2}-\mathbf{5}$. Invertebrate (?) egg-like problematic structures. 2 , UP $5 / 1 ; 3,5 / 2 ; 4,5 / 3 ; 5$, UP 5/4. Scale bar $0.5 \mathrm{~mm}$. 6, 7. Moulds of ostracoda. 6 UP $3 / 1 ; 3 / 2$. Scale bar $0.1 \mathrm{~cm}$. 8. Adult acanthodian Lodeacanthus gaujicus Upeniece, 1996, LDM 270/19, Length $3.12 \mathrm{~cm}$. Scale bar $1 \mathrm{~cm} .9$. Conchostraca Pseudestheria sp., UP $2 /$ 1. Scale bar $0.5 \mathrm{~cm}$. 10. Juvenile acanthodian Lodeacanthus gaujicus Upeniece, 1996, LDM 270/45a, estimated length $0.7 \mathrm{~cm}$. Scale bar $0.1 \mathrm{~cm}$. 11. Trace fossils of burrowing infauna, exposed under accumulation of adults of Asterolepis ornata, LDM $282 /$ 108. Scale bar $0.1 \mathrm{~cm}$. 

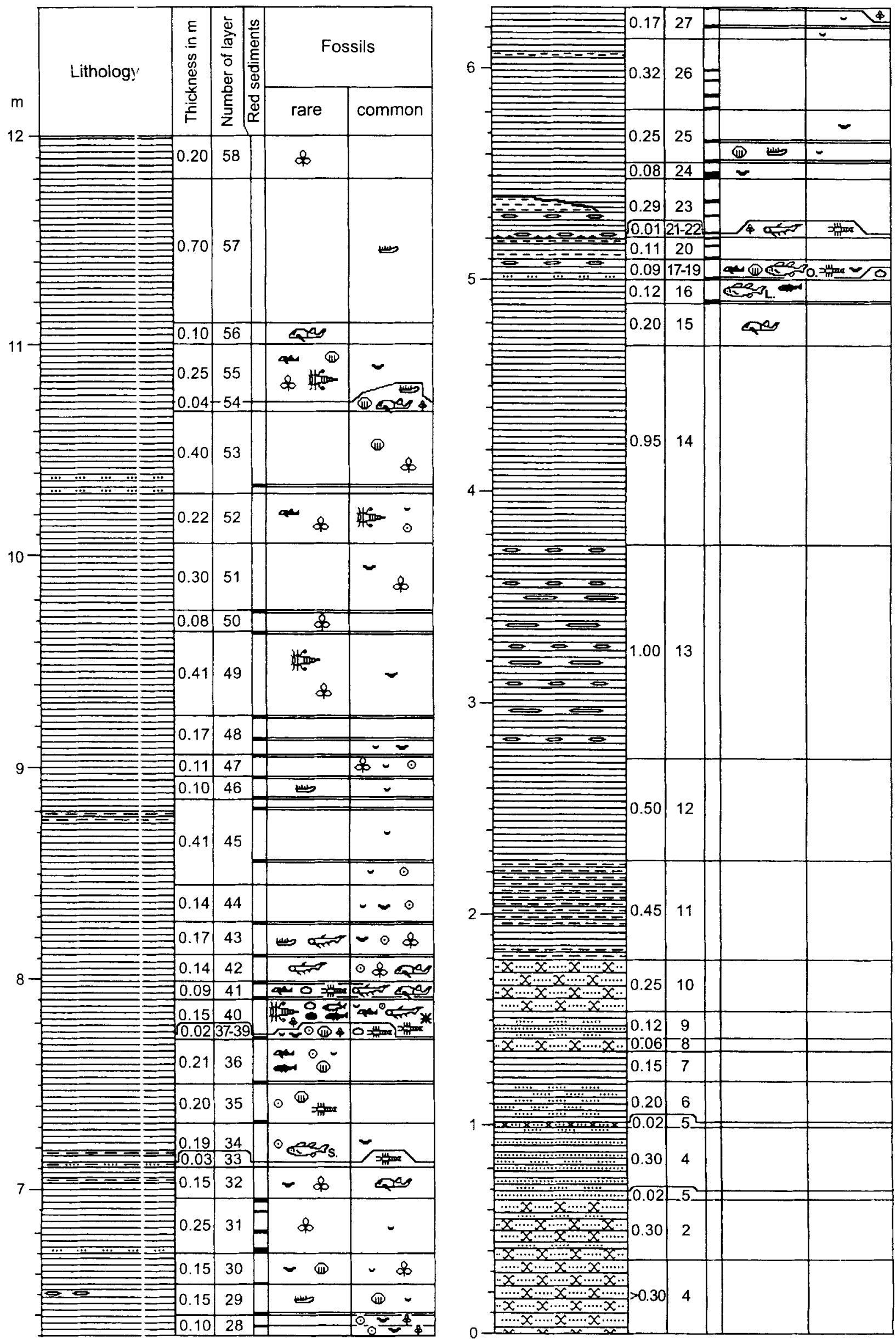


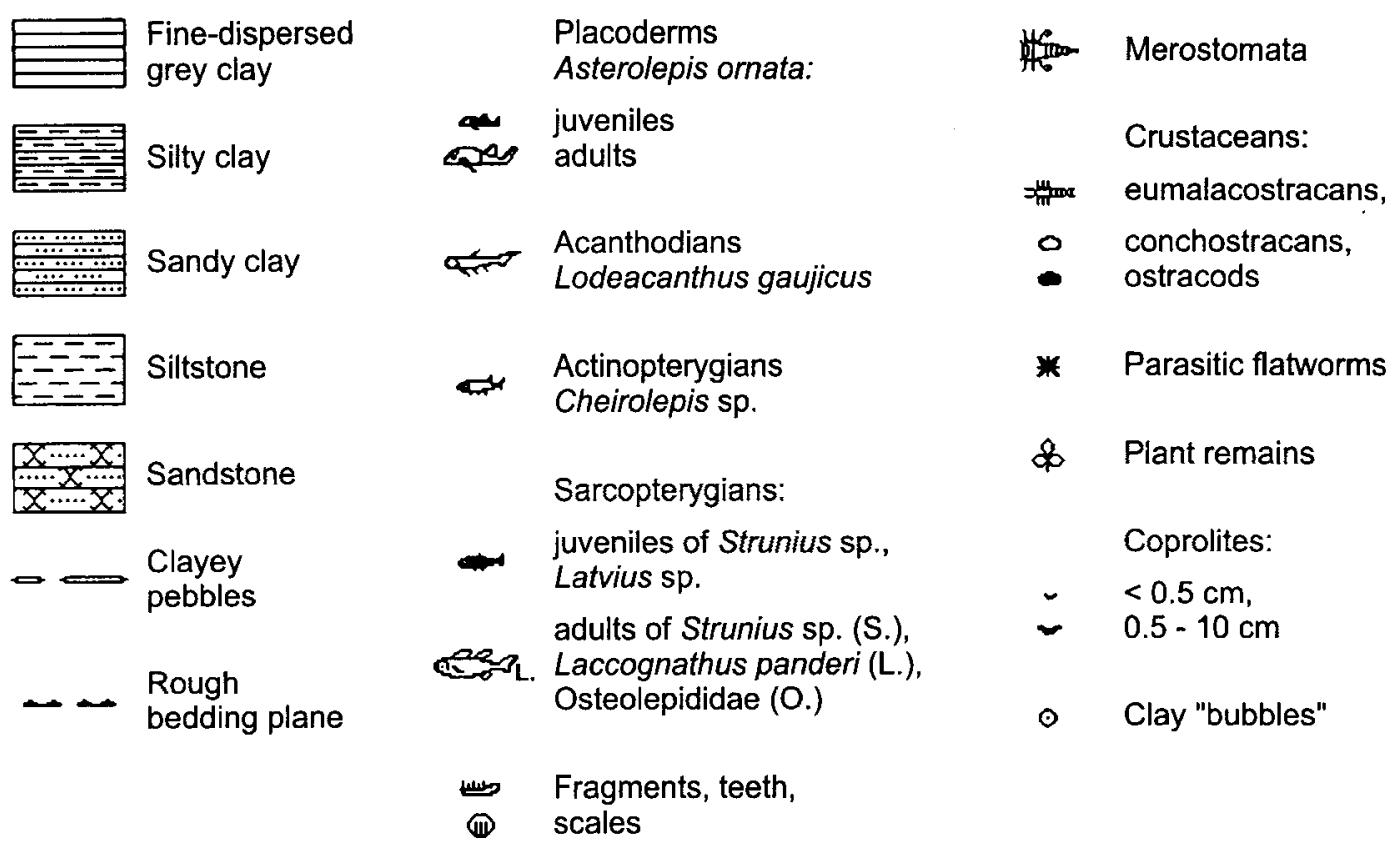

Fig. 2. Detailed biostratigraphical section of "juvenile fish" lens. Lode clay quarry, Latvia; lower Frasnian.

sliding down of the waterlogged clays. It is now a Latvian protected geological site.

\section{Vertebrates}

Vertebrates are juvenile and adult fish mostly of small size $(0.7-4 \mathrm{~cm})$. Extremely well-preserved complete juvenile individuals of four taxa occur: Asterolepis ornata, Lodeacanthus gaujicus, Strunius n. sp., and Latvius n. sp. (Upeniece 1996). Seldom fragmentary remains of Cheirolepis sp., and Coelacanthidae gen. et sp. indet. occur. The good preservation of both adult and juvenile specimens of the first three mentioned species provides information of sequence of certain growth stages. As in recent fishes, the main difference between juvenile and adult specimens is the relative size of the orbit and the head to total body length. The overwhelming majority of juvenile Asterolepis ornata (Col.-Pl. 1: 1-4, 6-7) are from layer Nr. 40. The ratio between asterolepids, acanthodians and sarcopterygians comprises about $50: 7: 1$.

Several adults of Asterolepis ornata also occur at some levels of this lens (Fig. 2), but separately from the juvenile fish findings; the dermal armour length of these comprise $30-35 \mathrm{~cm}$. All are poorly preserved as three-dimensional carcasses of powdery composition due to almost complete leaching, although the ornamentation of the bones is excellently preserved. An adult specimen of Laccognathus panderi was exposed in the lower part of the lens near the margin of the depression (layer Nr. 16), with total length of at least $1.65 \mathrm{~m}$ (previous findings reveal 0.8-1.3 m; Lyarskaya 1981: 39). This individual is not black or brown in colour, so characteristic for the fossils in this lens. Possibly it might be due to occurrence near the margin.

Juveniles of Asterolepis ornata: These reveal a sequence of growth stages, ranging from initial ossification of the dermal armour, to advanced juveniles (Upeniece \& Upenieks 1992). Approximately 95\% (more than 300) of the specimens are similar-sized individuals with total armour length (head plus trunk-shield) of $14.0-16.0 \mathrm{~mm}$. These could be individuals from one spawn. The smallest individual has a total armour length of $10.4 \mathrm{~mm}$, and the largest juvenile $38.0 \mathrm{~mm}$ (estimated). The smallest specimens reveal an unossified medio-ventral plate (Col.Pl. 1: 4). Unlike the adults, the juveniles had two dorsal and two ventral central plates in the distal segment. The terminale must have been accreted to the nearest central plate, but no sutural lines are visible in adults. The ridge system is extremely well developed in juveniles, giving strength to the armour when the laminae of bone are very thin.

Marked differences in morphology and shape peculiarities of young individuals of Asterolepis ornata have been found in MB. f. 7631 Juveniles reveal reticular ornamentation, which in larger individuals gradually changes into tubercles 
(Upeniece \& Upenieks 1992, Ivanov et al. 1995). The formation of the three-layer structure of the armour plates is visible. The smallest individuals (armour length $\sim 1 \mathrm{~cm}$ ) have one-layer structure of the armour and respectively have no developed ornamentation at all. Scales of juveniles have a thin larnina with one tubercle on the dorsal surface, corresponding to a pit on the visceral surface. In adults the scales are flat. These juvenile scales resemble those of several Early Devonian placodernıs, e.g. the antiarch Litijiangolepis from China (Wang S. 1987) and the tail fragment described as Asterosteus (Wang J. 1991. Ivanov et al. 1996), 0 " the scales of Stensioella (Gross 1962: figs $6 \mathrm{~B},(\mathrm{i})$.

More than 100 specimens of juvenile Asterolepis ornata show structures within the anterior part of the left side of the trunk shield (under left ADL plate). They are well visible from the dorsal, ventral or inner sides due to the arched armour plates over them. These structures appear with such regularity in position and shape that they must represent some internal organs of Asterolepis which communicated with the exterior. They are slongated and oriented lengthwise the body, and are filled with coprolitic-like material as is founc as discrete coprolites in the same clay lens. Carbonaceous and detritic-like bone material occur; in several cases, as well as numerous grains of quartz. This suggests that these remains are st mmach contents, with the stomach full of digested food matter at the time of death of the animal. The fossilised remains of the fish's last meal poin1 to mud grubber behaviour of the juvenile Asterolepis, as is known from the content of the intestine of Bothriolepis (Denison 1941). The position of the stomach (McAllister 1996) is close to the supposed lung of Denison (1941). In sev rral cases such stomach contents. but of smaller size, were found also under the right ADL. The stomach content of adult Asterolepis is not visible from the outside due to the heavy armour. which could have protected the comparatively softer stomach contents, but the carcasses cannot be opened for investigation without causin:s damage.

The fish bodies are more or less deformed, and often filed with clayey mud sediments which surround the animal. The thickness of sediment fillings reaches $0.1-1.0 \mathrm{~mm}$. It is considerably greater in the adults of Asterolepis ornata (up to several $\mathrm{cm}$ ) helping to preserve three-dimensionally the animal in some extent. Empty. and therefore more flattened and crashed juvenile specimens also occur.
Juvenile individuals of antiarchs are also known for Bothriolepis canadensis (Stensiö 1948), but these are larger specimens than Asterolepis. The smallest plates of juveniles of $\mathrm{Bo}$ thriolepis askinae from Antarctica (Young 1988) are a little larger than those in juveniles of Asterolepis ornata. The length of the smallest plates of Asterolepis ornata: AMD - $4.5 \mathrm{~mm}, \mathrm{PMD}-$ $2.4 \mathrm{~mm}$. ADL $-3.05 \mathrm{~mm}$, PDL $-4.15 \mathrm{~mm}$, AVL $-5.5 \mathrm{~mm}, \mathrm{PVL}-4.35 \mathrm{~mm}, \mathrm{Nu}-2.1 \mathrm{~mm}$, $\mathrm{La}-2.0 \mathrm{~mm}$. The length of the smallest plates of Bothriolepis askinae: AMD - under $5 \mathrm{~mm}$, PMD - $4.0 \mathrm{~mm}$ (ibid.: 43, 44). Very similar in both are the marked changes of shape with size of the ventral lamina of the AVL (ibid.: fig. 23C, D). Such changes in Asterolepis ornata occur in smaller juveniles (the length of the AVL plate $5.5 \mathrm{~mm})$ than in Bothriolepis askinae $(\sim 10 \mathrm{~mm}$, respectively). This might imply faster ontogeny in asterolepids. The smallest antiarch Minicrania (Yunnan. China) could represent both adult and juveniles. The smallest skull-roof is less than $2.2 \mathrm{~mm}$ in length; the entire dermal armour in the presumed adult is less than $20 \mathrm{~mm}$ in length (Zhu \& Janvier 1996).

Acanthodians: More than fifty individuals of Lodeacanthus gaujicus Upeniece, 1996 were found during the regular excavations. They represent both juvenile and adult individuals (Col.Pl. 2: 8, 10) with body length of 0.7 to $3.9 \mathrm{~cm}$ (both estimated). All developmental stages from juveniles without scales to fully scaled specimens are found (Upeniece 1996: pl. 1). One fourth of specimens are juveniles. In a few cases, the body is covered merely with a film of the skin; the head is indicated only by the presence of an eye stain. and a few branchiostegal rays, with fin spines and scapula confirming that it is an acanthodian (Col.-Pl. 2: 10; the length of LDM $270 / 45$ about $0.7 \mathrm{~cm}$ ). The next ontogenetic stage includes preserved circumorbital, nasal, and cheek bones, and initial stages of the scale covering of the body, which reaches the anal spine (ibid., fig. 2B); the estimated length of this specimen is $1.36 \mathrm{~cm}$ (LDM 270/28). The meckelian cartilage and palatoquadrate become ossified only after the scale covering of the body and the head is complete. From this ontogenetic stage the acanthodian individuals are considered to be adults. The length of the corresponding individuals is $2.35 \mathrm{~cm}$ (LDM 270/37). The longest known adult (ibid., pl. 4: 2) reaches a length of about $3.9 \mathrm{~cm}$ (LDM 270/38). Two specimens are prescrved with opened jaws, and 15 with closed 
jaws. This implies that acanthodians did not die of anoxia. Reddish-brown fragments of poorly preserved neurocrani occur in larger juveniles and adults. A few individuals reveal a brown coprolitic-like material in the intestine region.

Sarcopterygians: Several taxa of small sarcopterygians include juveniles and adults of Strunius $\mathrm{n}$. sp. (Upeniece 1995), juveniles of Latvius n. sp., as well as fragments of adults of Osteolepididae gen. et sp. indet. The juveniles of Strunius n. sp. are up to $2 \mathrm{~cm}$ long. They lack the harpoon-shaped sigmoid tooth tips which characterise the adults. The length of adult individuals is estimated to be at least $12 \mathrm{~cm}$ (incomplete caudal portion). Several bones of the adult reveal peculiar ornamentation. In addition, the scale cover and fragment of the anal and caudal fins of one juvenile coelacanth was found in 1994 (identified by H.-P. Schultze 1999 in Riga).

Actinopterygians: Fragments of the actinopterygian Cheirolepis sp. have also been found: 1) several detached head bones and scale cover; and (2) fragment of fin and scale cover. Minute scales and small fin rays suggest they could belong to juvenile individuals. Compared with the size of Cheirolepis canadensis from Miguasha (Schultze \& Cloutier 1996: fig. 3A) and of Cheirolepis trailli from Scotland (Trewin 1986: fig. 22) the Cheirolepis sp. from Lode probably represents juvenile individuals.

\section{Invertebrates}

Parasitic worms: Circlets of fossil hooks were found in 13 juveniles of Asterolepis ornata and in 24 specimens of Lodeacanthus gaujicus during study of morphology. The length of the hooks is $0.02-0.40 \mathrm{~mm}$. They are located in the gill region, near the fin spines, and in the abdominal region of acanthodians (Col-Pl. 3: 2). In asterolepids the location of the hooks is not so clear. The hooks must be remnants of parasitic organisms due to their specific location and occurence in different fishes. The length of infested fish is $1-4 \mathrm{~cm}$. Several of them were infested with two to nine parasites. Altogether 67 parasitic worm finds were made (Upeniece 1999b). Two of them were found in one individual of crustacean Mysidacea (the hooks seems to be too large for parasitism compared to the crustacean size), and one close to a specimen of Conchostraca.

Recent parasites possessing such hooks are known in phyla Platyhelminthes and Acanthoce- phala, where hooks are adapted for parasitism, and are used for attachment organ to the host. The circular arrangement of the bilaterally symmetrical located hooks and traces of a cuticular disc indicate that these examples could belong to the platyhelminth superclass Cercomeromorphae Bychowsky, 1957 (Schultz \& Gvozdev 1972), where larvae have radialy arranged chitin hooks for attachment. The size of the fossil hooks is about ten times larger than those in the modern Cercomeromorphae. Some hook systems may have affinities with the phylum Acanthocephala. The absence of modern analogues points to extinct groups of parasites.

No fossilised soft body parts were found, except traces of the disc outline. Diagnostic soft parts of parasitic helminths are absent. Different morphological groups of the hooks are presented in both species of fish. The hooks are of two types: with a handle and without. The hooks with handles occur in the abdominal region (endoparasites, Col-Pl. 3: 2). No fossil parasitic Platyhelminthes are described (Conway 1981, Grey 1988). Parasitic platyhelminth remains in juvenile fish bodies, this is their first discovery in the fossil record, and represents the oldest fossil record of fish parasites, as well as the oldest parasitic association ever found (cf. Boucot 1990: tables 4, $6,7,9)$. Examples of actual parasitism in the fossil record are rare.

With the exception of some eggs and larvae recorded from archaeological sites (Gooch 1975) the fossil record of parasitic Platyhelminthes is non-existent (Conway 1981). The only other known fossil flatworms are Miocene turbellarians from California (Pierce 1960), but they are freeliving taxa. Two Vendian genera were described from White Sea bank, but that they belong to the phylum Platyhelminthes, and are turbellarians, as proposed remains to be confirmed (Fedonkin 1985: 90). So far nothing about fossil parasitic flatworms is known (Grey 1988).

The fossil record of fish parasites is little known, with one record in the Palaeozoic, and one in the Mesozoic. Zangerl \& Case (1976) have described countless tiny fossil ellipsoidal bodies from the coprolitic rectal fill of the Pennsylvanian shark Cobelodus aculeatus (Cope), which they interpreted as a mass of helminth eggs, perhaps of cestode origin. Well-preserved Lower Cretaceous fossil parasitic copepods were described from the gill chambers of two skulls of the teleost fish Cladocyclus gardneri Agassiz from Brazil (Cressey \& Patterson 1973). 

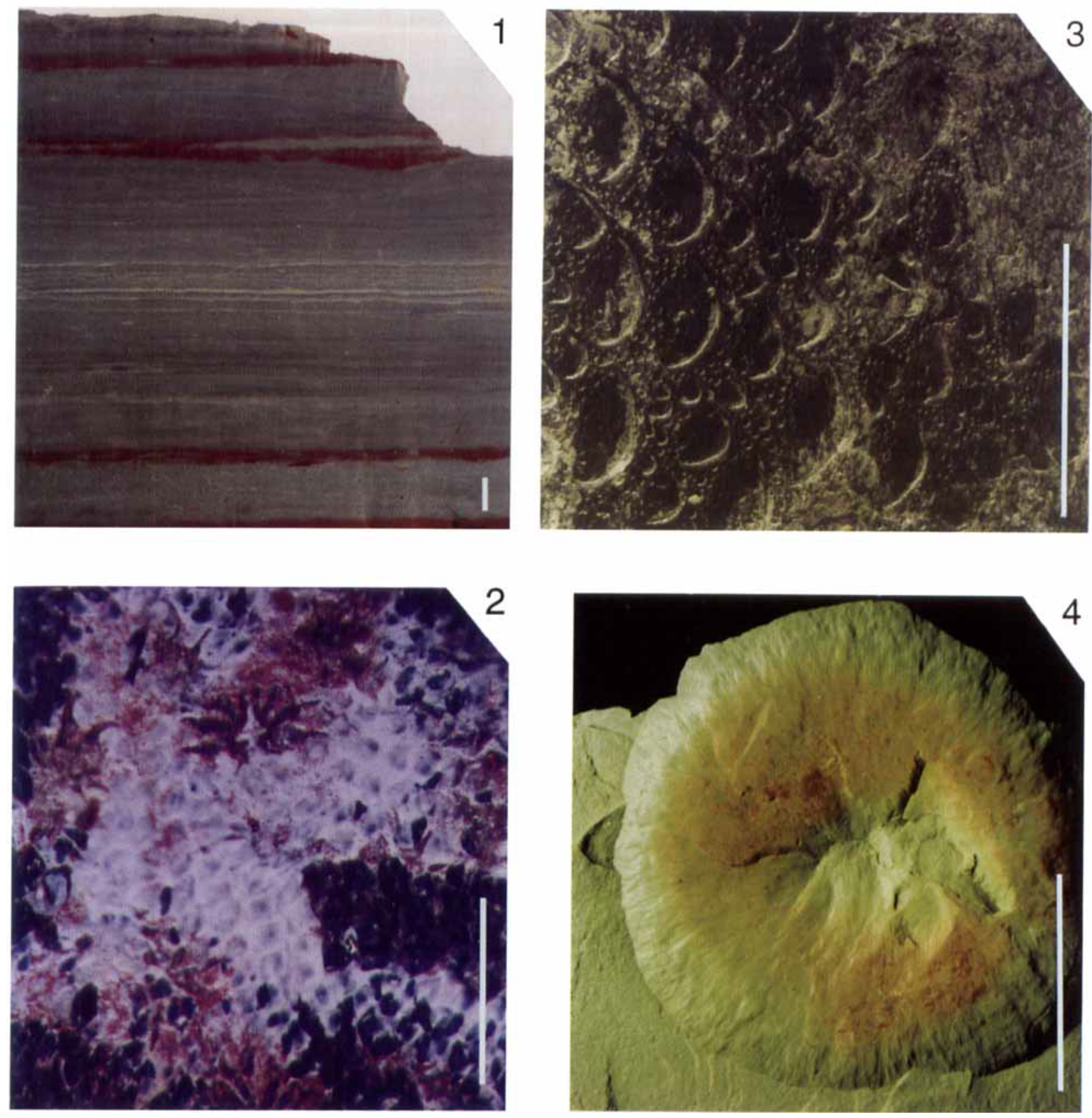

Colour-Plate 3. Grological and invertebrate specimens from the "juvenile fish" lens. Lode clay quarry, Latvia; lower Frasnian. 1. Finely-laminatell clays of the "juvenile fish" lens. layers $37-40$ (in Fig. 2). Scale bar $1 \mathrm{~mm}$. 2. Circlets of parasitic platyhelminth hooks insid: the acanthodian Lodeacanthus gaujicus. LDM 270/18c. Scale bar $1 \mathrm{~mm}$. 3. Fragment of abdominal segment of Eurypterida, UP 4/1. Scale bar $1 \mathrm{~cm}$. 4. Clay "bubble". originated from the decomposition gases of the soft-bodied organisms burried in clayey mud. UP $5 / 6$. Scale bar $0.5 \mathrm{~cm}$.

Crustacean ;: Thousands of well-preserved crustaceans of the order Mysidacea (class Malacostraca, subclass Eumalacostraca, superorder Peracarida) where found in this lens, representing the richest accumulations of eumalacostracans in the Devonian (Upenieks 1990). The Eumalacostraca are known from 7 Devonian localities from Euramerica, five of them in Europe (Schram 1977). Devonian malacostracan material is rase and poorly preserved (Schram 1980).
Complete specimens with eyes, uropods and two pairs of antennae are preserved (Col.-Pl. 2: 1). In some cases the stomach and intestine content occurs as a brown-powdery mass with carbonised remains occur. The mysidaceans must have served as fish food. Most mysidaceans are $1 \mathrm{~cm}$ long, but juvenile specimens of $0.5 \mathrm{~cm}$ long also occur. Almost all specimens are upside-down, with random orientation, implying post-mortem transportation. Several separately found individuals reach a length of $1.5 \mathrm{~cm}$. The body of 
Lode mysidaceans resembles that of the mold of a lost and undescribed specimen from the borehole at Kaluga, near Moscow, Upper Devonian (Schram 1980: pl. 1: 3).

Four layers with abundant accumulations of whole-bodied mysidaceans occur in this lens. In two layers (Nr. 22 and 33, Fig. 2) they are restricted to a $1-1.5 \mathrm{~cm}$ thick silt/sandstone interlayer, where accumulation in several bedding planes occur. The preservation of their carapaces is extremely different: in layer Nr. 22 mysidaceans are white in colour, and react with $\mathrm{HCl}$, without any traces of chitin covering; in the layer Nr. 33 the chitin covering is completely preserved (Col.Pl. 2: 1). Two levels of mysidaceans are restricted to clays $(\mathrm{Nr} .19,39)$, the chitin is nearly translucent and is thought to be the result of moulting.

Conchostracans are common fossils within a narrow zone of reddish-brown fine-dispersed clays within layer Nr. 37. They form a taphocoenosis together with the alga Platyphyllum sp. They are translucent, usually both shells are preserved, and their length is up to $1 \mathrm{~cm}$. They occur also irregularly within layers containing Asterolepis juveniles. Some conchostracans are identified as Pseudestheria sp. (Col.-Pl. 2: 9) by their concentric growth lines and characteristic reticular microornamentation between. At least three new taxa of conchostracans may be present.

Ostracods are preserved only as moulds of $0.3-1.3 \mathrm{~mm}$ length. They are oval and smooth and no specific morphological features can be observed. Commonly the moulds of both shells are present; sometimes they are in open position. Their shell might have been a very thin structure. Ostracods are found near the Asterolepis ornata juveniles as well as on separate bedding plane of variegated clays (Col.-Pl. 2: 6,7).

Many crustacean remains are incertae sedis.

Eurypterids: Eurypterids (Merostomata) only occur as fragmental material, but are readily identified by their specific semilunar ornamentation on the segments (Col.-Pl. 3: 3). The carbonate material is completely leached, and only chitin is preserved. These are the first finds of eurypterids in the Gauja regional stage, and they belong to new taxa. Both adult and juvenile specimens are recorded.

The adults are estimated to be about $1 \mathrm{~m}$ in length, exceeding those found in the deposits of the Salaspils and Pļavingas regional stages of lower Frasnian, Latvia. Eurypterids are known to be inhabitants of brackish waters; they may have been feeding on smaller invertebrates.

\section{Problematic remains}

Problematic soft-bodied and phosphatic remains are common. Unfortunately, it is not possible to identify most of them systematically (Col.Pl. 1: 5). Several egg-like structures (Col.-Pl. 2: 2-5) could belong to invertebrates, judging by their small size. Separate "eggs" also are collected, - they reveal a peculiar pit on the surface (blastula?).

Clay "Bubbles": Clay "bubbles" are abundant throughout the clay lens. They are interpreted to have originated due to decomposition gases enclosed in the sediment around decaying soft-bodied organisms. These resulted in concentric circles above and below the assumed organisms or their remains (Col.-Pl. 3: 4). Evidence supporting this is the fact that many bubbles contain coprolites of various sizes. As the organic part of the coprolite decayed, gas was formed, and a bubble-like clay structure was produced. The linear-shaped coprolites produce oval form clay "bubbles". In one case, evidence of the gas escaping process was observed in the middle part of the ventral wall of an adult Asterolepis ornata, with a clay bubble approximately $4 \mathrm{~cm}$ in diameter lying between the margins of $\mathrm{MV}$ and PVL plates.

\section{Trace fossils}

Coprolites: Coprolites are exceedingly abundant throughout the section (Fig. 2). They vary in shape and in structure, and are derived from both carnivores and herbivores. Herbivorous coprolites contain carbonised plant fragments. Several scroll coprolites (Col.-Pl. 4: 7, 8) contain bony material, acanthodian scales and spines, and small scales of sarcopterygians (Latvius $\mathbf{n}$. sp., Strunius n. sp.). The material is present both on the surface and in the interior of the coprolites. Some coprolites contain twisted parts of acanthodian bodies, making it obvious that their spines did not prevent ingestion of the whole animal. The spines of acanthodians are normally rare in coprolites (McAllister 1989, 1996: 344 . Trewin \& Davidson 1996, fig. 8a).

Ichnofossils: Ichnofossils are almost absent in the "juvenile fish" lens, but there are a few samples with horizontal trace fossils. 

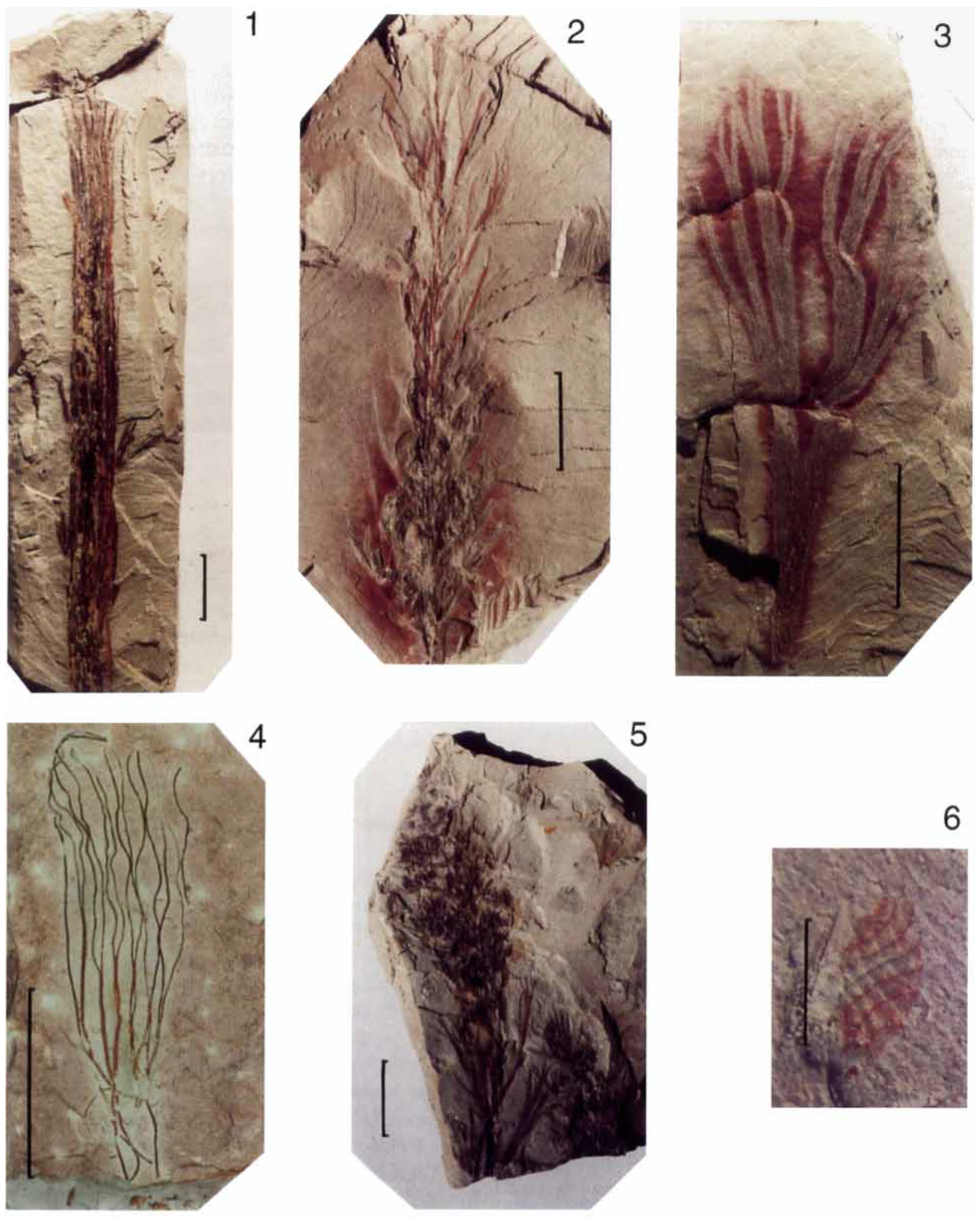

6
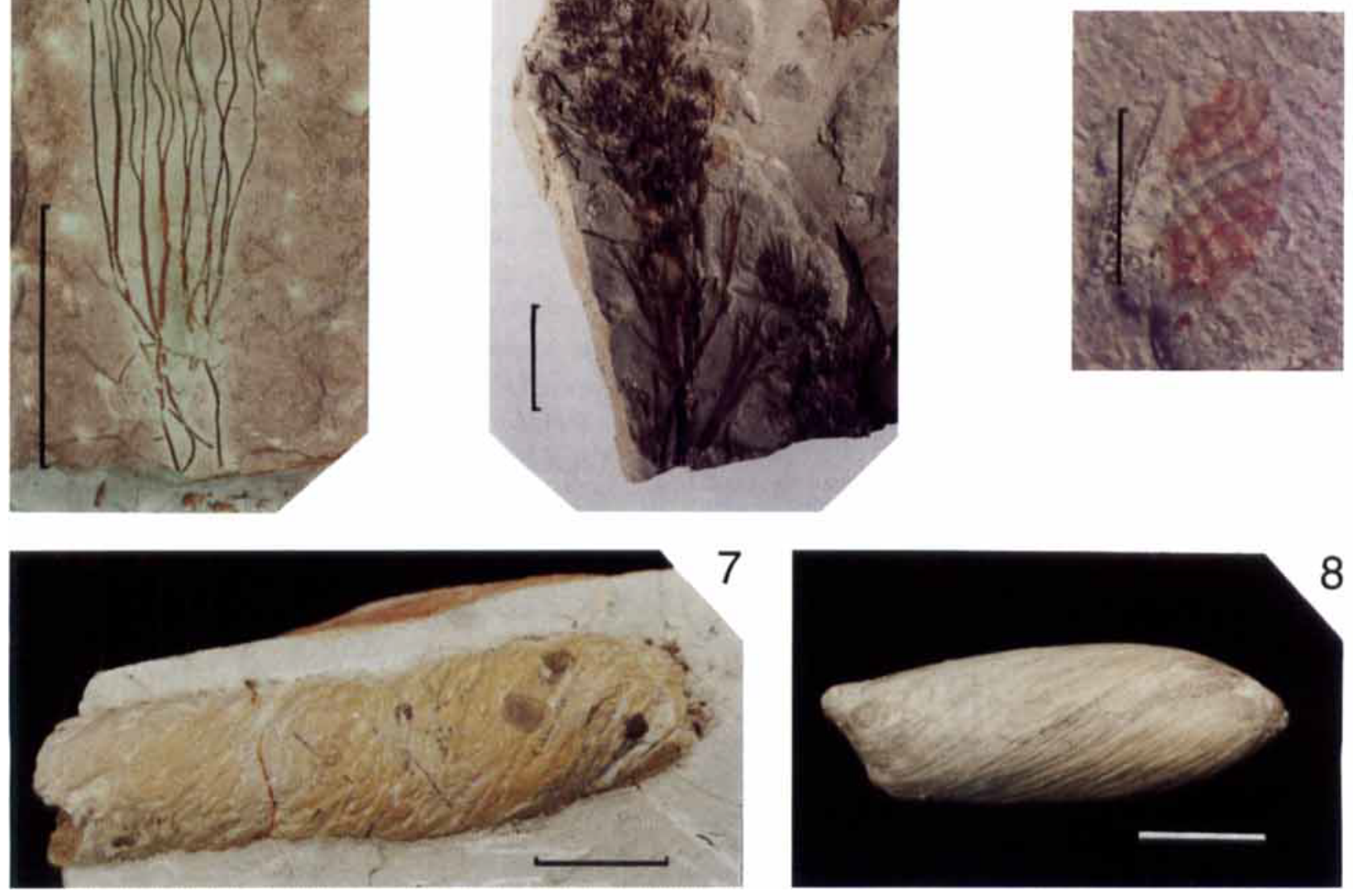


\section{Plants}

An oogonium of the charophyte Trochilliscus sp. has been found in the stomach content of an $A s$ terolepis ornata juvenile during the preparation of thin sections. Two finds of Charophyta g. et sp. indet. with a left coil could belong to Charales (Col.-Pl. 4: 6). Algae are represented by Platyphyllum sp. (Col.-Pl. 4: 4) and Progymnospermopsida by Svalbardia polymorpha Høeg, 1942 (Col.-Pl. 4: 2, 3, 5) and Archaeopteris fissilis Schmalhausen, 1894 (Col.-Pl. 4: 1). Svalbardia and Archaeopteris could be synonyms (Meyen 1987: 136). Megaspores presumed to belong to Archaeopteris, which resemble those in Meyen (1987: fig. 35f), have been found near and on the juveniles of Asterolepis ornata.

\section{Comparison with similar ichthyofaunas of other areas}

The whole Devonian sequence in the Main Devonian Field (East Baltic area: Estonia, Latvia, Lithuania, and N-W part of Russia and Byelorussia) nowadays contains more than 270 different taxa at the specific level (Esin et al. 2000, Mark-Kurik 2000). Early Frasnian sedimentation in the Main Devonian Field continued through Gauja, Amata and Plavingas regional stages with similar ichthyofaunas, and the ichthyofaunas resemble those from several other areas (Table 2).

The species and generic composition of the Gauja Regional Stage assemblage resembles those from the Amata and Plaviņas regional stages of the Main Devonian Field:

1) Gauja and Amata regional stages comprises 10 common and stratigraphically limited species: Psammolepis venyukovi, Ps. undulata, Plourdosteus livonicus, Devononchus concinnus, D. laevis, Homacanthus gracilis, Nostolepis gaujensis, Glyptolepis baltica, Laccognathus panderi, and Panderichthys rhombolepis. These regional stages represent similar terrigenous facies and yield no conodonts to determine the Givetian/ Frasnian boundary.
2) Amata and Pḷaviņas regional stages comprise four common and stratigraphically limited species: Psammosteus praecursor, Ps. maeandrinus, Ps. asper, and Asterolepis radiata. Eight shared genera are known: Psammosteus, Plourdosteus, Asterolepis, Bothriolepis, Glyptolepis, Laccognathus, Holoptychius, and Eusthenopteron. Facies are different (terrigenous and carbonatic, respectively).

3) Gauja and Pļaviņas regional stages comprise 10-12 shared genera: Psammosteus, Plourdosteus, Asterolepis, Bothriolepis (?), Haplacanthus, Glyptolepis, Laccognathus, Holoptychius (?), Panderichthys, Latvius, Eusthenopteron, and Strunius.

The Gauja Regional Stage comprise five transitional species from the upper Givetian in common with the Main Devonian Field: Ganosteus stellatus, Haplacanthus marginalis, Rhadinacanthus multisulcatus, Homacanthus gracilis, and Grossipterus crassus (Table 2).

Outside the Main Devonian Field the most similar Late Devonian assemblages are known from the South, Middle and North Timan sections; eight species could be similar to early Frasnian Regional Stage: Psammolepis cf. undulata, Psammosteus praecursor, P. maeandrinus, $P . c f$. cuneatus, Plourdosteus ex gr. mironovi, Asterolepis radiata, Bothriolepis obruchevi, and $B$. cellulosa. At least 11-12 genera are similar to the Gauja Regional Stage vertebrates (Table 2): Psammolepis, Psammosteus, Plourdosteus, Asterolepis, Bothriolepis (?), Devononchus, Haplacanthus, Homacanthus, Glyptolepis, Laccognathus, Holoptychius, and Latvius.

The Scottish sequence is missing an equivalent of the Gauja Regional Stage (Ahlberg et al. 1999). Similar to the Main Devonian Field ichthyofauna are two species from Givetian?/ Frasnian of Scotland: Psammolepis undulata (similar to Gauja and Amata regional stages), and Plourdosteus mironovi? (similar to Plavinas Regional stage) and six to seven genera: Psammolepis, Plourdosteus, Asterolepis, Bothriolepis, Laccognathus, Panderichthys?, and Eusthenopteron. The late Givetian vertebrate genera of Scotland

Colour-Plate 4. Micro- and macro-plant remains and coprolites of "juvenile fish" lens. Lode clay quarry, Latvia; lower Frasnian.

1. Archaeopteris fissilis Schmalhausen, 1894, LDM 282/105. Scale bar $1 \mathrm{~cm}$. 2, 3, 5. Svalbardia polymorpha Høeg, 1942, LDM 282/100, 282/101, 282/102. Scale bar $1 \mathrm{~cm}$. 4. Alga Platyphyllum sp., LDM 282/103. Scale bar $1 \mathrm{~cm}$. 6: Charophyta Charales (?), left coil, LDM 282/104. Scale bar $0.1 \mathrm{~cm}$. 7, 8. Scroll coprolites. 7, LDM 282/106. 8. with sarcopterygian scales, LDM 282/ 107. Scale bar $0.5 \mathrm{~cm}$. 


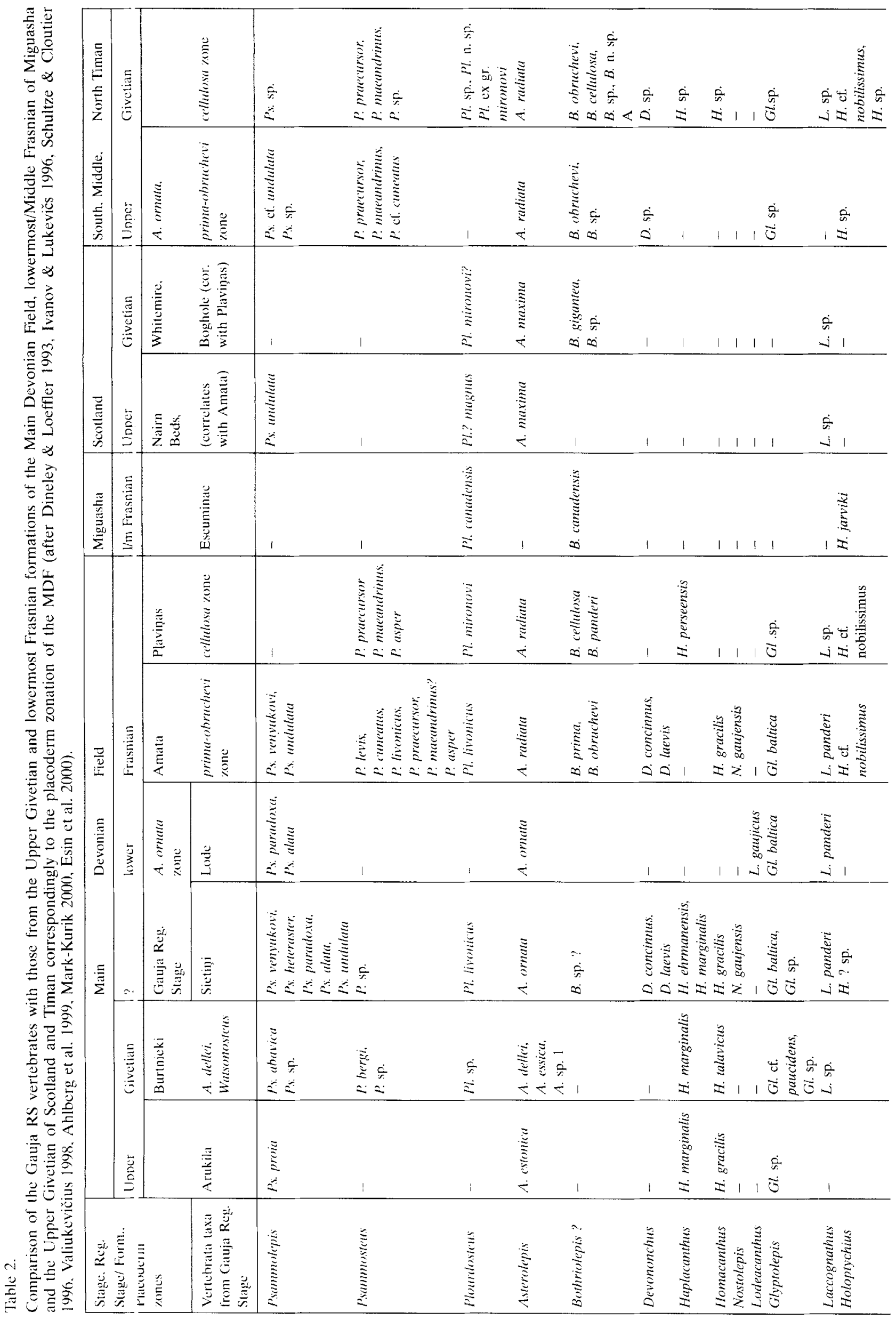



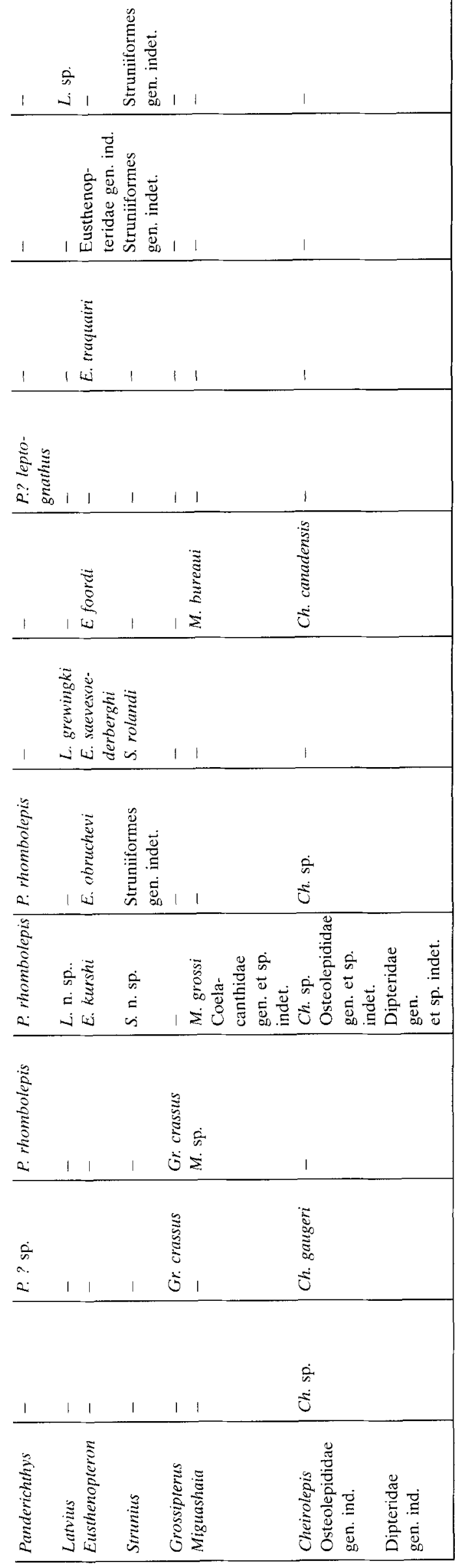

well coincide with those from Baltic area: Watsonosteus, Microbrachius, Dickosteus?, Millerosteus?, and Homostius (Ahlberg et al. 1999).

The faunal assemblages on the generic levels of fishes of the early Frasnian regional stages of the Main Devonian Field (Esin et al. 2000, Mark-Kurik 2000) are similar to the Frasnian Escuminac Formation, Miguasha (Schultze \& Cloutier 1996) as follows:

1) Gauja Regional Stage: four to six shared genera: Cheirolepis, Plourdosteus, Miguashaia, Bothriolepis (?), Eusthenopteron, and Holoptychius (?).

2) Amata Regional Stage: five shared genera: Cheirolepis, Bothriolepis, Plourdosteus, Holoptychius, and Eusthenopteron. The most important fossil site is the locality Pasta muiža.

3) Plavinas Regional Stage: four shared genera: Bothriolepis, Plourdosteus, Holoptychius, and Eusthenopteron. The most important fossil site is the locality Koknese.

"Stensiö (1948) correlated the Escuminac Formation with the Cellulosa marl (Plavingas Formation) of Latvia based on the presence of the antiarch Bothriolepis canadensis and B. cellulosa, respectively" (Cloutier et al. 1996: 191). The megaplant fossils of Archaeopteris halliana and A. obtusa are known from the Escuminac Formation. Lode Formation characterises the $A r$ chaeopteris fissilis. That genus characterises the Frasnian-early Fammenian, as mentioned already in the introduction.

The above mentioned three regional stages comprise similar genera also to the Frasnian Okse Bay Formation, Ellesmere Island, Canada (Cloutier \& Lelièvre 1998) as follows: Psammosteus, Glyptolepis, Holoptychius, and Bothriolepis. Two genera: Strunius and Latvius are similar to those in the Frasnian of the Oberer Plattenkalk Formation, Bergisch-Gladbach, Germany (Cloutier \& Lelièvre 1998).

In conclusion, the Gauja Regional Stage ichthyofauna is more similar to the Frasnian faunal assemblages of the Main Devonian Field, Timan, Scotland, and of Miguasha, than to faunas of late Givetian age.

\section{Acknowledgements}

The author thanks to Prof. H.-P. Schultze (Museum für Na turkunde, Berlin) and Dr. G. Young (Canberra, Australia) for the reviews of the manuscript and the linguistic help; 10 Dr. N. Petrosjan for the identification of Svalbardia, Archaeopteris and Platyphyllum (1990 in VSEGEI, St. Petersburg); to Dr. L. Gailite, Institute of Geology, Riga (2001) for 
the identification of ostracods Lepedites sp. Special thanks to Mrs. Velga Lice (Riga) for the helpful assistance during the excavations of fos sils and Mr. Jannis Upenieks (Riga) for the loaning of the art rropod and problematic specimens for the photographing and the comments of their brief description. The "juvenile fish" Iens and the accumulations of crustaceans were found by hin in 1984 .

\section{References}

Ahlberg. P.. Clack. J. \& Lukševičs. E. 1996. Rapid braincase evolution between Panderichthys and the earliest tetrapods. - Naturs 381: 61-64.

Ahlberg. P.. Ivan sv, A.. Lukševičs. E. \& Mark-Kurik. E. 1999. Middle and Upper Devonian correlation of the Baltic area and Scotland based on fossil fishes. In Lukševičs. E.. Stinkulis. C. \& Kalnina. L. (eds). Problems and methods of modern regional stratigraphy. The $4^{\text {th }}$ Baltic Stratigraphical Conf zrence. Abstracts: $6-8$.

Blieck, A.. Turner. S. \& Young. G. with contributions of Lukševičs. E., Mark-Kurik. E.. Talimaa. V. \& Valiukevičius, J. 2000 . Cevonian vertebrate biochronology and global marine/non-marine correlation. - Courier Forschungsinstitut Sencke berg 220: $161-193$.

Boucot. A. 1990. Evolutionary Paleobiology of Behavior and Coevolution. I:Isevier. Amsterdam. Oxford. New York. Tokyo: $1-725$.

Cloutier. R. \& Lelièvre. H. 1998. Comparative Study of Devonian Fossilif rous Sites. Prepared for the ministère de l'Environneme at et de la Faune. Gouvernement du Québec: V+86: unf ublished.

Cloutier. R. Loboziak. S. Candilier. A.-M. \& Blieck. A. 1996. Biostrati sraphy of the Upper Devonian Escuminac Formation, eastern Québec. Canada: a comparative study based on miospores and fishes. - Review for Palaebotany and Palynology 93: $191-215$

Conway. M. 1981. Parasites and the fossil record. - Parasitology 82: 489 - 509 .

Cressey. R. \& Paterson. C. 1973. Fossil parasitic copepods from a Lover Cretaccous fish. - Science 180 . $1283-1285$.

Denison. R. 1941. The soft anatomy of Bothriolepis. - Journal of Paleontelogy 15 (5): 553-561.

Dincley. D. L. \& Loeffler. E. 1993. Biostratigraphy of the Silurian and Levonian gnathostomes of the Euramerica Province. In L ong. J. (ed.). Palaeozoic vertebrate biostratigraphy and biogeography. Belhaven Press. London: $104-138$.

Elder, R. \& Smiti. G. 1988. Fish taphonomy and environmental inference in paltelimnology. - Palaeogeography. Palaeoclimatol,gy. Palaefecology 62 (4): $577-592$

Esin. D., Ginter. V.. Ivanov. I., Lebedev. O.. Lukševičs. E., Avkhimovich. V.. Golubtsov. V. \& Petukhova. L. 2000. Vertebrate cor elation of the Upper Devonian and Lower Carboniferous on the East European Platform. - Courier Forschungsinst tut Senckenberg 223: $341-359$

Fedonkin. M. 198: [Phylum Platyhelminthes.] In Sokolov. B. \& Ivanovskij. 1. (eds). Vendian svstem. 1: 90-92. Nauka. Moscow. [In Russian].

Forev. P.. Ahlberg. P. Lukšcvičs. E. \& Zupinš. I. 2000). A new coelacanth from the Middle Devonian of Latvia. - Journal of Vertebrc te Paleontology 20 (2): 243-252

Gooch. P. S. 1975 Helminths in archaeological and pre-historic deposits. - Annotated Bibliography of the Commonwealth Ins itute of Helminthology 9: $1-15$

Grey. J. 1988. Evo ution of the freshwater ecosystem: the fossil record. - Palacogeography. Palaeoclimatology. Palaeoecology 62 (1): 1-215. Amsterdam.

Gross. W. 1962. Neuuntersuchung der Stensioellida (Arthrodira. Unterdev m). - Notizblatt des Hessischen Landesamtes für Bodt nforschung 90: 48-86.
Gunter. G. 1947. Catastrophism in the sea and its paleontological significance, with special reference to the Gulf of Mexico. - American Journal of Science 245 (11): $669-676$.

Ivanov. A. \& Lukševičs, E. 1996. Late Devonian vertebrates of Timan. - Daba un Muzejs 6: 22-32.

Ivanov. A.. Cherepanov, G. \& Lukševičs, E. 1995. Ontogenetic development of Antiarchi dermal ossifications. Geobios. Mémoire spécial 19: 97-102.

Ivanov, A.. Lukševičs. E. \& Upeniece, I. 1996. Squamous part of an asterolepid body. - Modern Geology 20 $(3-4): 399-409$

Kuršs. V. 1975. [Lithology and Mineral Resources of the Terrigenous Devonian of the Main Devonian Field.] 216 pp., Zinatne. Riga. [In Russian with English summary].

- 1986. [Successions of facies types of sediments and burial conditions of fishes in the Early-Middle Devonian basins of Latvia.] In Biofacies and fauna of the Silurian and Devonian basins in the East Baltic: 61-72, Zinatne, Riga. [In Russian].

- 1992a. SSedimentation of Devonian clastics on the Main Devonian Field.] 208 pp., Zinatne, Riga. [In Russian].

- 1992b. Depositional environment and burial conditions of fish remains in Baltic Middle Devonian. In Mark-Kurik, E. (ed.). Fossil Fishes as Living Animals. Academia 1: $251-260$

Kuršs. V. \& Lyarskaya, L. 1973. [Taphonomy of ichthyofauna in clays of the Lode quarry and some problems on the palaeogeography of North East Baltic in the Early Frasnian time.] In Problems of regional geology of the East Baltic and Byelorussia: 109-119. Zinatne, Riga [In Russian].

Kuršs. V.. Lukševičs, E., Upeniece, I. \& Zupiņš, I. 1998 [Upper Devonian clastics and associated fish remains in Lode clay quarry. Latvia (part I).] - Latvijas Geologijas Vestis 5: 7-19. [In Latvian with English summary].

- 1999. [Upper Devonian clastics and associated fish remains in Lode clay quarry, Latvia (part II)]. - Latvijas Geologijas Vestis 6: 10-17. [In Latvian with English summary].

Lvarskava. L. 1972. [The first find of the whole-bodied skeletons of placoderm fish in the Upper Devonian of Latvia.] In Problems on regional geology of Baltic and Byelorussia: 198-207. Zinatne. Riga. [In Russian].

1977. [New data on Asterolepis ornata Eichwald from Early Frasnian deposits of Baltic.] In Menner V. V. (ed.). Notes on phylogeny and systematic of fossil fish and agnathans: 36-45, NAUKA, Moscow. [In Russian].

- 1981. [Devonian Placoderms from the Baltic. Asterolepididae]: 152 pp., Zinatne, Riga. [In Russian with English summary].

Lyarskaya. L. \& Mark-Kurik, E. 1972. Eine neue Fundstelle oberdevonischer Fische im Baltikum. - Neues Jahrbuch für Mineralogie. Geologie und Paläontologie. Monatshefte. Jahrgang 1972 (7): 407-414.

Mark-Kurik. E. 1999. Miospore assemblage from the Lode member (Gauja Formation) in Estonia and the MiddleUpper Devonian boundary problem. - Proceedings of the Estonian Academy of Sciences 48 (2): 86-98.

McAllister. J. A. 1989. Preliminary description of the coprolitic remains from Hamilton Quarry, Kansas. In: Mapes, G. \& Mapes. R. (eds). Regional geology and paleontology of upper Paleozoic Hamilton quarry area in southeastern Kansas. Kansas Geological Survey, Guidebook Scries 6 [for 1988]: 195-202.

- 1996. Coprolitic remains from the Devonian Escuminac Formation. In Schultze, H.-P. \& Cloutier, R. (eds) Devonian Fishes and Plants of Miguasha, Quebec, Canada. Verlag Dr. Friedrich Pfeil, München: 328-347.

Mark-Kurik. E. 2000. The Middle Devonian fishes of the Baltic States (Estonia, Latvia) and Belarus. - Courier Forschungsinstitut Senckenberg 223: 309-324.

Meyen. S. 1987. [The principles of paleobotany.] $403 \mathrm{pp}$., NEDRA. Moscow. [In Russian]. 
Ørvig, T. 1957. Remarks on the vertebrate fauna of the lower Upper Devonian of Escuminac Bay, P.Q., Canada, with special reference to the porolepiform crossopterygians. Arkiv för Zoologi 2(10): 367-426.

Pierce, W. D. 1960. Silicified Turbellaria from Calico Mountains nodules. - Bulletin Southern Californian Academy of Sciences 59: 138-143.

Schram, F. 1977. Paleozoogeography of Late Paleozoic and Triassic Malacostraca. - Systematic Zoology 26: 367--379.

- 1980. Miscellaneous Late Paleozoic Malacostraca of the Soviet Union. - Journal of Paleontology 54 (3): 542-547.

Schultz, R. S. \& Gvozdev, J. V. 1972. [The principles of helminthology.] Part 2, 515 pp., NAUKA, Moscow. [In Russian].

Schultze, H.-P. \& Cloutier, R. 1996. Comparison of the Escuminac Formation ichthyofauna with other late Givetian/ early Frasnian ichthyofauna. In Schultze, H.-P. \& Cloutier, R. (cds). Devonian Fishes and Plants of Miguasha, Quebec, Canada. Verlag Dr. Friedrich Pfeil, München: $348-368$.

Stensiö, E. 1948. On the Placodermi of the Upper Devonian of East Greenland. 2. Antiarchi: subfamily Bothriolepinae. With an attempt at the revision of the previously described species of that sub-family. - Palaeozoologica Groenlandica 2: 1-622.

Trewin, N. 1986. Palaeocology and sedimentology of the Achanarras fish bed of the Middle Old Red Sandstone, Scotland. - Transactions of the Royal Society of Edinburgh: Earth Sciences 77: 21-46.

Trewin, N. \& Davidson, R. 1996. An Early Devonian lake and its associated biota in the Midland Valley of Scotland. - Transactions of the Royal Society of Edinburgh: Earth Sciences 86: 223-246.

Upeniece. I. 1991. Types of fossil fish taphocoenoses of the Lode Formation in Latvia. - Bulletin of the Geological Survey of Estonia 1 (1): 13.

- 1995. New species of Strunius (Sarcopterygii, Onychodontida) from Latvia, Lode Quarry (Upper Devonian). In Lelièvre H., Wenz, S., Blieck, A. \& Cloutier, R. (eds). Premiers Vertébrés et Vertébrés Inférieurs. - Geobios, Mémoire spécial 19: 281-284

- 1996. Lodeacanthus gaujicus n. g. et sp. (Acanthodii: Mesacanthidae) from the Late Devonian of Latvia. - Modern Geology 20 (3-4): 383-398.

- 1999a. The sequence of disarticulation of Asterolepis ornata body and associated taphocoenoses. In Lukševičs, E., Stinkulis, G. \& Wilson. M. V. H. (eds). Lower-Middle Palaeozoic Events across the Circum-Arctic. Ichthyolith Issues Special Publication 5: 48-50.

- $1999 \mathrm{~b}$. Fossil record of parasitic helminths in fishes. - Abstracts of the "5th International Symposium on Fish Parasites": 154, Ceske Budejovice, August, 1999.

- 2000. The unique fauna of Lode quarry (Devonian, Latvia). In Antoshkina, A., Malysheva, E. \& Wilson, M. V. H. Pan-Arctic Palaeozoic Tectonies, Evolution of Basins and Faunas. Ichthyolith Issues Special Publication 6: $127-133$

- 2001. Trophic relations of the Lode organism assemblage, Lower Frasnian, Latvia. - Abstracts. Obruchev Symposium Evolutionary Palaeoichthyology: 45.
Upeniece, I. \& Upenieks, J. 1992. Young Upper Devonian antiarch (Asterolepis) individuals from the Lode quarry. Latvia. In Mark-Kurik, E. (ed.). Fossil fishes as living animals. Academia 1: $167-176$

Upenieks, J. 1990. [Devonian crustaceans in Lode clay sediments.] - Annual of Nature and History 1990: 234-235. [In Latvian].

Valiukevičius, J. 1998. Acanthodians and zonal stratigraphy of Lower and Middle Devonian in East Baltic and Byelorussia. - Palaeontographica A 248: 1-53.

Vorobyeva, E. I. 1980. Observations on two rhipidistian fishes from the Upper Devonian of Lode, Latvia. - Journal Linnean Society London, Zoology 70: 191-201

- 1989. [Panderichthiids - a new order of Palaeozoic sarcopterygians (Rhipidistia).] - Academy of Science of USSR 306(1): 188-189. [In Russian].

- 1995. The shoulder girdle of Panderichthys rhombolepis (Gross) (Crossopterygii), Upper Devonian, Latvia. In Lelièvre, H., Wenz, S., Blieck, A. \& Cloutier, R. (eds.). Premiers vertébrés et vertébrés inférieurs. - Geobios. Mémoire Spécial 19: 285-288.

Vorobyeva, E. I. \& Schultze, H.-P. 1991. Description and systematics of Panderichthyid Fishes with comments on their relationship to Tetrapods. In Schultze, H.-P. \& Trueb. L. (eds). Origins of the Higher Groups of Tetrapods. Controversy and Consensus: 68-109. Cornell University Press, Ithaca, London.

Wang J. 1991. [Discovery of Asterosteidae from Lower Devonian in eastern Yunnan.] - Vertebrata Palasiatica 29(2): 162-164. [In Chinese with English summary].

Wang S. 1987. (A new antiarch from the Early Devonian of Guangxi.] - Vertebrata Palasiatica 25 (2): 81-90. [In Chinese and English].

Worobjewa, E. J. 1973. Einige Besonderheiten im Schädelbau von Panderichthys rhombolepis (Gross) (Pisces, Crossopterygii). - Palaeontographica A 143: 221-229.

- 1975. Bemerkungen zu Panderichthys rhombolepis (Gross) aus Lode in Lettland (Gauja-Schichten, Oberdevon). Neues Jahrbuch für Mineralogie, Geologie und Paläontologie, Monatshefte, Jahrgang 1975 (5): 315-320.

Young, G. 1988. Antiarchs (placoderm fishes) from the Devonian Aztec Siltstone, Southern Victoria Land, Antarctica. - Palaeontographica A 202: 1-125.

Zangerl, R. \& Case, G. R. 1976. Cobelodus aculeatus (Cope), an anacanthous shark from Pennsylvanian black shales of North America. - Palaeontographica A 154: 107-157.

Zhu M. \& Janvier, P. 1996. A small antiarch, Minicrania lir ouyii gen. et sp. nov., from the Early Devonian of Qujing. Yunnan (China), with remarks on antiarch phylogeny. Journal of Vertebrate Paleontology 16 (1): 1-15.

Zupiņš, I. 2000. New information of the morphology of Glyptolepis baltica Gross (Osteichthyes, Porolepiforms). In Antoshkina, A., Malysheva, E. \& Wilson, M. V. H. (eds) Pan-Arctic Palaeozoic Tectonics, Evolution of Basins and Faunas. Ichthyolith Issues Special Publication 6: 161.

- 2001. [Taxonomy and distribution of Tristichopteridae (Sarcopterygii, Osteolepiformes) from the Main Devonian Field.] M.Sc., May 9th, 2001. University of Latvia. Unpublished, 49 pp. [In Latvian with English and Russian summary]. 